\title{
Productivity and Quality of Greengram as Influenced by Potassium and Zinc Nutrition
}

\author{
Mohammad Javid Rahimi*, Y. Reddi Ramu, N. Sunitha and V. Umamahesh
}

Department of Agronomy, S.V. Agricultural College, Tirupati-517502, Acharya N.G. Ranga Agricultural University, Andhra Pradesh, India

*Corresponding author

\section{Keywords}

Quality of

Greengram,

Potassium and Zinc

Nutrition

Article Info

Accepted:

07 May 2019

Available Online:

10 June 2019

\section{A B S T R A C T}

A field experiment was conducted during kharif, 2018 at S.V. Agricultural College, dryland farm, Tirupati to test the effect of potassium and zinc on yield and quality of greengram with eight nutrient management practices viz., Control $\left(\mathrm{T}_{1}\right)$, application of Recommended Dose of Fertilizers (RDF) (20-50-0 kg N, $\mathrm{P}_{2} \mathrm{O}_{5}$ and $\left.\mathrm{K}_{2} \mathrm{O} \mathrm{ha}^{-1}\right)\left(\mathrm{T}_{2}\right)$, soil application of $40 \mathrm{~kg} \mathrm{~K}_{2} \mathrm{O} \mathrm{ha}^{-1}$ along with RDF ( $\left.\mathrm{T}_{3}\right) 25 \mathrm{~kg}$ of $\mathrm{ZnSO}_{4} \mathrm{ha}^{-1}$ along with RDF ( $\left.\mathrm{T}_{4}\right) 40 \mathrm{~kg} \mathrm{~K} 2 \mathrm{O}+25 \mathrm{~kg}$ of $\mathrm{ZnSO}_{4} \mathrm{ha}^{-1}$ along with $\mathrm{RDF}\left(\mathrm{T}_{5}\right)$ Foliar application of either $\mathrm{KNO}_{3} @ 1.0 \%\left(\mathrm{~T}_{6}\right) \mathrm{ZnSO}_{4} @ 0.2 \%\left(\mathrm{~T}_{7}\right)$ along with $\mathrm{RDF}$ and $\mathrm{KNO}_{3} @ 1.0 \%$ and $\mathrm{ZnSO}_{4}$ @ $0.2 \%$ at flower bud initiation along with $\mathrm{RDF}\left(\mathrm{T}_{8}\right)$ at flower bud initiation. Potassium and zinc were applied basally in the form of Muriate of Potash, $\mathrm{ZnSO}_{4}$ and foliar application of potassium and zinc in the form of $\mathrm{KNO}_{3} @ 1.0 \%$ and $\mathrm{ZnSO}_{4} @ 0.2 \%$ at flower bud initiation. The highest seed yield, haulm yield and harvest index of greengram was recorded with foliar application of $1 \% \mathrm{KNO}_{3}+0.2 \% \mathrm{ZnSO}_{4}$ at flower bud initiation stage along with $\mathrm{RDF}\left(\mathrm{T}_{8}\right)$, which was however comparable with soil application of $40 \mathrm{~kg}$ $\mathrm{K}_{2} \mathrm{O}+25 \mathrm{~kg}$ of $\mathrm{ZnSO}_{4} \mathrm{ha}^{-1}$ along with $\mathrm{RDF}\left(\mathrm{T}_{5}\right)$ and significantly superior over the rest of the nutrient management practices tried. Foliar application of $1 \% \mathrm{KNO}_{3}+0.2 \% \mathrm{ZnSO}_{4}$ at flower bud initiation stage along with RDF $\left(\mathrm{T}_{8}\right)$ recorded significantly higher protein and zinc content in the grain, which was however comparable with foliar application of $0.2 \%$ $\mathrm{ZnSO}_{4}$ at flower bud initiation stage along with $\mathrm{RDF}\left(\mathrm{T}_{7}\right)$ significantly superior over the rest of the nutrient management practices tried.

\section{Introduction}

India is one of the major pulses growing country of the world, accounting roughly for one third of total world area under pulse cultivation and one fourth of total world production. Pulses occupy a key position in Indian diet and meet about 30 per cent of the daily protein requirement. Green gram commonly known as "mung" or "mung bean" is the most important crop of the South-East Asia and particularly the Indian subcontinent. This popular and ancient crop is specially recognized as an excellent source of protein. It also plays an important role in maintaining and improving the fertility of soil through its ability to fix atmospheric nitrogen in the soil by root nodules. Potassium is one 
of the essential nutrient for plant growth and vital for sustaining modern high yield agriculture. Under intensive cropping without $\mathrm{K}$ fertilization, leads to depletion of potassium from the soil. Factors which can lead to potassium deficiency are leaching in sandy soils, irrigation water with high sodium content and where high rates of $\mathrm{Ca}$ and $\mathrm{Mg}$ are added through the irrigation water or through fertilization. Besides, the current N P $\mathrm{K}$ use ratio $(6.8: 2.8: 1)$ when viewed from a generally proclaimed ideal ratio of $4: 2: 1$ was unfavourable to potassium availability (Katyal, 2012). Among the micronutrients, zinc deficiency is the most common deficiency prevalent in the world (Alloway, 2004). Zinc deficiency in Indian soils is expected to increase from 42 per cent in 1970 to 63 per cent by 2025 due to continuous depletion of soil fertility.

\section{Materials and Methods}

A field experiment was carried out during kharif, 2018 at S.V. Agricultural College, dryland farm, Tirupati, which is geographically situated at $13.5^{\circ} \mathrm{N}$ latitude and $79.5^{\circ} \mathrm{E}$ longitude. The experimental soil was sandy loam in texture, neutral in reaction $(\mathrm{pH}$ $6.9)$, low in organic carbon $(0.45 \%)$, available nitrogen $\left(152.5 \mathrm{~kg} \mathrm{ha}^{-1}\right)$, available phosphorus $\left(20.52 \mathrm{~kg} \mathrm{ha}^{-1}\right)$, available potassium $(135.4 \mathrm{~kg}$ $\left.\mathrm{ha}^{-1}\right)$ and zinc $\left(1.04 \mathrm{~kg} \mathrm{ha}^{-1}\right)$. The experiment was laid out in randomized block design and replicated thrice with eight treatments which include RDF i.e. $20 \mathrm{~kg} \mathrm{~N}$ and $40 \mathrm{~kg} \mathrm{P}_{2} \mathrm{O}_{5} \mathrm{ha}^{-1}$, The treatments consisted of eight nutrient management practices viz., Control $\left(\mathrm{T}_{1}\right)$, application of Recommended Dose of Fertilizers (RDF) (20-50-0 kg N, $\mathrm{P}_{2} \mathrm{O}_{5}$ and $\left.\mathrm{K}_{2} \mathrm{O} \mathrm{ha}^{-1}\right)\left(\mathrm{T}_{2}\right)$, soil application of $40 \mathrm{~kg} \mathrm{~K}_{2} \mathrm{O}$ $\mathrm{ha}^{-1}$ along with RDF $\left(\mathrm{T}_{3}\right)$, soil application of $25 \mathrm{~kg} \mathrm{ZnSO}_{4} \mathrm{ha}^{-1}$ along with $\mathrm{RDF}\left(\mathrm{T}_{4}\right)$, soil application of $40 \mathrm{~kg} \mathrm{~K}_{2} \mathrm{O} \mathrm{ha}{ }^{-1}+25 \mathrm{~kg} \mathrm{ZnSO}_{4}$ $\mathrm{ha}^{-1}$ along with RDF $\left(\mathrm{T}_{5}\right)$, foliar application of $\mathrm{KNO}_{3} @ 1 \%$ at flower bud initiation stage along with $\mathrm{RDF}\left(\mathrm{T}_{6}\right)$, foliar application of $\mathrm{ZnSO}_{4} @ 0.2 \%$ at flower bud initiation stage along with RDF $\left(\mathrm{T}_{7}\right)$, foliar application of $1 \%$ $\mathrm{KNO}_{3}+0.2 \% \mathrm{ZnSO}_{4}$ at flower bud initiation stage along with $\mathrm{RDF}\left(\mathrm{T}_{8}\right)$ (Table 1$)$. The fertilizers were applied as per the treatments in the farm of urea, single super phosphate and murate of potash, zinc sulphate and potassium nitrate. The weeds were controlled with pre emergence application of pendimethalin@1 Kg a.i ha ${ }^{-1}$ and one hand weeding was done at 17DAS. The seeds of greengram were sown at a spacing of $30 \mathrm{~cm} \mathrm{x}$ $10 \mathrm{~cm}$ on $13^{\text {th }}$ of July with seed rate of $15 \mathrm{~kg}$ $\mathrm{ha}^{-1}$. The crop was harvested in three pickings manually based on physiological maturity of pods. Data pertaining to yield attributes and yield were collected at harvest and analyzed statistically. Greengram variety IPM 2-14 T the crop was harvested on 9-10-2018. The grain samples collected at harvest were ground into fine powder and analysed for assessing the different quality parameters. Total protein of the seeds from different treatments was determined by Lowry's method (1951). Zinc content of the seeds from different treatments was determined by Atomic absorption spectrophotometer (Tandon, 1993).

\section{Results and Discussion}

\section{Seed yield}

Seed yield of greengram was significantly influenced by soil and foliar application of potassium and zinc (Table 1). The highest seed yield $\left(1770 \mathrm{~kg} \mathrm{ha}^{-1}\right)$ of greengram was recorded with foliar application of $1 \% \mathrm{KNO}_{3}$ $+0.2 \% \mathrm{ZnSO}_{4}$ at flower bud initiation stage along with RDF $\left(\mathrm{T}_{8}\right)$, which was however comparable with soil application of $40 \mathrm{~kg}$ $\mathrm{K}_{2} \mathrm{O}+25 \mathrm{~kg}$ of $\mathrm{ZnSO}_{4} \mathrm{ha}^{-1}$ along with RDF $\left(\mathrm{T}_{5}\right)$ and significantly superior over the rest of the nutrient management practices tried. foliar application of $1 \% \mathrm{KNO}_{3}+0.2 \% \mathrm{ZnSO}_{4}$ at 
flower bud initiation stage along with RDF $\left(\mathrm{T}_{8}\right)$, and soil application of $40 \mathrm{~kg} \mathrm{~K}_{2} \mathrm{O}+25$ $\mathrm{kg}$ of $\mathrm{ZnSO}_{4} \mathrm{ha}^{-1}$ along with $\mathrm{RDF}\left(\mathrm{T}_{5}\right)$ resulted in 98.8 and 93.8 per cent higher seed yield compared to control $\left(\mathrm{T}_{1}\right)$. Seed yield of greengram is a function of yield attributes, which were significantly higher with this nutrient management practice. The increase in seed yield ascribed due to the reason that application of potassium along with zinc possibly increased the availability of $\mathrm{N}, \mathrm{P}$ and $\mathrm{K}$ in soil solution and ultimately resulted in the vigorous root development, which promotes growth and development of the plant leading to higher photosynthetic activity which in turn results in better development of yield attributes and finally higher seed yield (Chavan et al., 2012). These results are corroborated with the findings of Yadav and Hira Nand (2004).

Foliar application of $0.2 \% \mathrm{ZnSO}_{4}$ at flower bud initiation stage along with $\operatorname{RDF}\left(\mathrm{T}_{7}\right)$ and soil application of $25 \mathrm{~kg} \mathrm{ZnSO} \mathrm{Zha}^{-1}$ along with RDF $\left(\mathrm{T}_{4}\right)$, foliar application of $1 \%$ $\mathrm{KNO}_{3}$ at flower bud initiation stage along with RDF ( $\left.\mathrm{T}_{6}\right)$ and soil application of $40 \mathrm{~kg}$ $\mathrm{K}_{2} \mathrm{O}$ ha $^{-1}$ along with RDF $\left(\mathrm{T}_{3}\right)$, were the next best treatments, which were comparable each other and significantly superior over RDF $\left(\mathrm{T}_{2}\right)$ alone.

Foliar application of $1 \% \mathrm{KNO}_{3}+0.2 \% \mathrm{ZnSO}_{4}$ at flower bud initiation stage and pod formation stage along with $\mathrm{RDF}\left(\mathrm{T}_{8}\right)$ resulted in 2.60 per cent higher seed yield over soil application of $40 \mathrm{~kg} \mathrm{~K}_{2} \mathrm{O}+25 \mathrm{~kg} \mathrm{ZnSO}_{4} \mathrm{ha}^{-1}$ along with $\mathrm{RDF}\left(\mathrm{T}_{5}\right)$. The favorable effect of foliar application of potassium might be attributed to key role of potassium in phytomass production and pod filling particularly at post anthesis period and thereby increased photosynthetic activity and effective translocation of assimilates to reproductive parts resulting in more number of seeds $\operatorname{pod}^{-1}$, test weight and higher seed yield (Mengal, 1976). Zinc has a direct influence on auxin production, which in turn enables the plant to produce more dry matter and consequently enhanced the partitioning of photosynthates towards newly formed sink, which resulted in early bloom, prolonged flowering period and better development of yield attributes leading to higher seed yield (Mostafavi, 2012). Control (T1) recorded the lowest seed yield $\left(890 \mathrm{~kg} \mathrm{ha}^{-1}\right)$ due to reduced growth parameters and yield attributes and finally lower yield due to deficiency of potassium and zinc as the experimental soils are poor in available potassium $(135.4 \mathrm{~kg}$ $\mathrm{ha}^{-1}$ ) and available zinc (1.04 $\left.\mathrm{kg} \mathrm{ha}^{-1}\right)$. Similar results were also reported by Nalini et al., (2013) in blackgram and Beg et al., (2013) in urdbean. The superiority of foliar nutrition might be to coincidence of foliar application with peak nutrient requirement of the crop, moreover peak absorption of potassium occurs from flowering to early pod development, any deficiency of potassium during this period can result in yield loss without obvious foliar symptoms. The quantity of nutrients absorbed due to soil application of potassium and zinc may not be sufficient to meet the crop demands at pod development stage. Supplementing the nutrients through foliage at flowering and pod formation stages might have resulted in better nutrient balance and thereby regaining the photosynthetic efficiency of the plant at post anthesis period results in increased yield attributes and seed yield of redgram (Reddy et al., 1991).

\section{Haulm yield}

Among all the nutrient management practices, the highest haulm yield of greengram (2928 $\mathrm{kg} \mathrm{ha}^{-1}$ ) was recorded with foliar application of $1 \% \mathrm{KNO}_{3}+0.2 \% \mathrm{ZnSO}_{4}$ at flower bud initiation stage along with $\mathrm{RDF}\left(\mathrm{T}_{8}\right)$, which was however comparable with soil application of $40 \mathrm{~kg} \mathrm{~K} 2 \mathrm{O}+25 \mathrm{~kg}$ of $\mathrm{ZnSO}_{4} \mathrm{ha}^{-1}$ along 
with RDF $\left(T_{5}\right)$ which was significantly superior over the rest of the nutrient management practices tried. The improvement in the haulm yield might be due to indirect and positive role of potassium in formation and proliferation of lateral and fibrous roots, which increases the root absorbing surface area for nutrients, which in turn promotes the growth parameters and ultimately enhanced the stalk yield (Chavan et al., 2012). These findings were in accordance with those of Patel and Kotecha (2006). Zinc play a prime role in the biosynthesis of IAA, which is in turn promotes the vertical growth leading to higher LAI and dry matter production and thereby resulting in higher stalk yield. The above results are in agreement with those of Babu et al., (2012).

The next best treatment was foliar application of $0.2 \% \mathrm{ZnSO}_{4}$ at flower bud initiation stage along with $\operatorname{RDF}\left(\mathrm{T}_{7}\right)$ which was however comparable with soil application of $25 \mathrm{~kg}$ $\mathrm{ZnSO}_{4} \mathrm{ha}^{-1}$ along with $\mathrm{RDF}\left(\mathrm{T}_{4}\right)$, foliar application of $1 \% \quad \mathrm{KNO}_{3}$ at flower bud initiation stage along with $\mathrm{RDF}\left(\mathrm{T}_{6}\right)$ and soil application of $40 \mathrm{~kg} \mathrm{~K}_{2} \mathrm{O}$ ha $^{-1}$ along with RDF $\left(\mathrm{T}_{3}\right)$, and were significantly superior over $\operatorname{RDF}\left(\mathrm{T}_{2}\right)$ alone. The lower haulm yield (2251 $\mathrm{kg} \mathrm{ha}{ }^{-1}$ ) was recorded with application of recommended dose of fertilizers $\left(\mathrm{T}_{2}\right)$ due to imbalanced nutrition caused by non supply of potassium and zinc. Control (T1) recorded significantly the lowest straw yield due to non supply of nutrients.

\section{Harvest index}

The highest harvest index in greengram was recorded with foliar application of $1 \% \mathrm{KNO}_{3}$ $+0.2 \% \mathrm{ZnSO}_{4}$ at flower bud initiation stage along with $\operatorname{RDF}\left(\mathrm{T}_{8}\right)$. This might be due to better absorption and translocation of all the nutrients in balanced proportion including potassium and zinc where foliar application coincides with the peak crop demand and thereby maintenance of better source-sink relationship. The lowest harvest index was recorded with in control $\left(\mathrm{T}_{1}\right)$ due to poor source-sink relationship.

\section{Quality parameters}

\section{Protein content}

Soil and foliar application of potassium and zinc have exerted significant influence on protein content of seeds. Foliar spray of potassium and zinc increased the protein content considerably over soil application (Table 2).

Foliar application of $1 \% \mathrm{KNO}_{3}+0.2 \% \mathrm{ZnSO}_{4}$ at flower bud initiation stage along with RDF $\left(\mathrm{T}_{8}\right)$ recorded significantly higher protein content (26.32 per cent), which was however comparable with foliar application of $0.2 \%$ $\mathrm{ZnSO}_{4}$ at flower bud initiation stage along with $\mathrm{RDF}\left(\mathrm{T}_{7}\right)$ significantly superior over the rest of the nutrient management practices tried. The next best treatment was soil application of $40 \mathrm{~kg} \mathrm{~K} 2 \mathrm{O}+25 \mathrm{~kg}$ of $\mathrm{ZnSO}_{4}$ $\mathrm{ha}^{-1}$ along with RDF $\left(\mathrm{T}_{5}\right)$, foliar application of $1 \% \mathrm{KNO}_{3}$ at flower bud initiation stage along with RDF $\left(\mathrm{T}_{6}\right)$ and soil application of $25 \mathrm{~kg}$ $\mathrm{ZnSO}_{4}$ ha $^{-1}$ along with $\mathrm{RDF}\left(\mathrm{T}_{4}\right)$, soil application of $40 \mathrm{~kg} \mathrm{~K}_{2} \mathrm{O} \mathrm{ha}^{-1}$ along with RDF $\left(\mathrm{T}_{3}\right)$, and application of recommended dose of fertilizers $\mathrm{RDF}\left(\mathrm{T}_{2}\right)$ alone. The lowest protein content was recorded with control $\left(\mathrm{T}_{1}\right)$

Higher protein content associated with $\left(\mathrm{T}_{8}\right)$ might be due to the role of these nutrients in nodulation and biological nitrogen fixation in legume crops, owing to increased nitrogen content, as nitrogen is an important constituent of proteins (Demeterio et al., 1972). Zinc plays a major role in the metabolism of plant as an activator of several enzymes which in turn directly or indirectly affect the synthesis of carbohydrates and proteins (Anitha et al., 2005). Further, foliar 
spray of zinc keeps RNase enzyme activity by binding the sulphohydryl group and thus protecting disulphide formation which leads to increased protein synthesis (Pandey et al., 2010). The lowest protein content (18.62 per cent) was recorded with control $\left(\mathrm{T}_{1}\right)$, as the available nitrogen in the soil may not be sufficient to meet the demands of sink at post anthesis period.

Table.1 Seed yield, stalk yield $\left(\mathrm{kg} \mathrm{ha}^{-1}\right)$ and harvest index of greengram as influenced by soil and foliar application of potassium and zinc

\begin{tabular}{|c|c|c|c|}
\hline Treatments & $\begin{array}{c}\text { Seed yield } \\
\left(\mathrm{kg} \mathrm{ha}^{-1}\right)\end{array}$ & $\begin{array}{l}\text { Stalk } \\
\text { yield } \\
\left(\mathrm{kg} \mathrm{ha}^{-1}\right)\end{array}$ & $\begin{array}{l}\text { Harvest } \\
\text { index }(\%)\end{array}$ \\
\hline$T_{1}$ : control (no fertilizers application) & 890 & 1740 & 33.84 \\
\hline$T_{2}:$ Recommended dose of fertilizer (RDF) & 1243 & 2251 & 35.57 \\
\hline $\mathrm{T}_{3}: \mathrm{T}_{2}+$ Soil application of $40 \mathrm{~kg} \mathrm{~K}_{2} \mathrm{O} \mathrm{ha}^{-1}$ & 1440 & 2550 & 36.10 \\
\hline $\mathrm{T}_{4}: \mathrm{T}_{2}+$ Soil application of $25 \mathrm{~kg} \mathrm{ZnSO}_{4} \mathrm{ha}^{-1}$ & 1493 & 2592 & 36.54 \\
\hline $\begin{array}{l}\mathrm{T}_{5}: \mathrm{T}_{2}+\text { Soil application of } 40 \mathrm{~kg} \mathrm{~K}_{2} \mathrm{O} \mathrm{ha}^{-1}+25 \\
\mathrm{~kg} \mathrm{ZnSO}_{4} \mathrm{ha}^{-1}\end{array}$ & 1725 & 2898 & 37.36 \\
\hline $\begin{array}{l}\mathrm{T}_{6}: \mathrm{T}_{2}+\text { Foliar application of } \mathrm{KNO}_{3} @ 1 \% \text { at } \\
\text { flower bud initiation stage. }\end{array}$ & 1472 & 2580 & 36.33 \\
\hline $\begin{array}{l}\mathrm{T}_{7}: \mathrm{T}_{2}+\text { Foliar application of } \mathrm{ZnSO}_{4} @ 0.2 \% \text { at } \\
\text { flower bud initiation stage }\end{array}$ & 1554 & 2608 & 37.34 \\
\hline $\begin{array}{l}\mathrm{T}_{8}: \mathrm{T}_{2}+\text { Foliar application of } \mathrm{KNO}_{3} @ 1 \%+ \\
\mathrm{ZnSO}_{4} @ 0.2 \% \text { at flower bud initiation stage. }\end{array}$ & 1770 & 2928 & 37.68 \\
\hline SEm \pm & 40.0 & 81 & \\
\hline $\mathrm{CD}(\mathbf{P}=\mathbf{0 . 0 5})$ & 123 & 250 & \\
\hline
\end{tabular}

Table.2 Protein (\%) and zinc content (ppm) of greengram seed as influenced by soil and foliar application of potassium and zinc

\begin{tabular}{|c|c|c|}
\hline Treatments & $\begin{array}{l}\text { Protein } \\
\text { content } \\
(\%)\end{array}$ & $\begin{array}{l}\text { Zinc } \\
\text { content } \\
(\mathbf{p p m})\end{array}$ \\
\hline$T_{1}:$ control (no fertilizers application) & 18.62 & 36 \\
\hline$T_{2}:$ Recommended dose of fertilizer (RDF) & 21.96 & 41.89 \\
\hline $\mathrm{T}_{3}: \mathrm{T}_{2}+$ Soil application of $40 \mathrm{~kg} \mathrm{~K}_{2} \mathrm{O} \mathrm{ha}^{-1}$ & 22.18 & 42.98 \\
\hline $\mathrm{T}_{4}: \mathrm{T}_{2}+$ Soil application of $25 \mathrm{~kg} \mathrm{ZnSO}_{4} \mathrm{ha}^{-1}$ & 22.34 & 46.96 \\
\hline $\mathrm{T}_{5}: \mathrm{T}_{2}+$ Soil application of $40 \mathrm{~kg} \mathrm{~K}_{2} \mathrm{O} \mathrm{ha}^{-1}+25 \mathrm{~kg} \mathrm{ZnSO}_{4} \mathrm{ha}^{-1}$ & 23.20 & 48.39 \\
\hline $\begin{array}{l}\mathrm{T}_{6}: \mathrm{T}_{2}+\text { Foliar application of } \mathrm{KNO}_{3} @ 1 \% \text { at flower bud } \\
\text { initiation stage. }\end{array}$ & 22.51 & 45.04 \\
\hline $\begin{array}{l}\mathrm{T}_{7}: \mathrm{T}_{2}+\text { Foliar application of } \mathrm{ZnSO}_{4} @ 0.2 \% \text { at flower bud } \\
\text { initiation stage }\end{array}$ & 26.08 & 52.89 \\
\hline $\begin{array}{l}\mathrm{T}_{8}: \mathrm{T}_{2}+\text { Foliar application of } \mathrm{KNO}_{3} @ 1 \%+\mathrm{ZnSO}_{4} @ 0.2 \% \\
\text { at flower bud initiation stage. }\end{array}$ & 26.32 & 54.12 \\
\hline SEm \pm & 0.76 & 1.08 \\
\hline $\mathrm{CD}(\mathbf{P}=\mathbf{0 . 0 5})$ & 2.32 & 3.33 \\
\hline
\end{tabular}




\section{Zinc content}

The highest zinc content in the seed was registered with foliar application of $1 \% \mathrm{KNO}_{3}$ $+0.2 \% \mathrm{ZnSO}_{4}$ at flower bud initiation stage along with $\mathrm{RDF}\left(\mathrm{T}_{8}\right)$, which was however comparable with foliar application of $\mathrm{ZnSO}_{4}$ (a) $0.2 \%$ at flower bud initiation stage along with $\operatorname{RDF}\left(\mathrm{T}_{7}\right)$ and these nutrient management practices were significantly superior over the rest of the treatments. soil application of 40 $\mathrm{kg} \mathrm{K}_{2} \mathrm{O} \mathrm{ha}^{-1}+25 \mathrm{~kg} \mathrm{ZnSO}_{4}$ ha $^{-1}$ along with $\mathrm{RDF}\left(\mathrm{T}_{5}\right)$ and soil application of $25 \mathrm{~kg} \mathrm{ZnSO}_{4}$ $\mathrm{ha}^{-1}$ along with RDF $\left(\mathrm{T}_{4}\right)$ were comparable among themselves and significantly superior over treatments were zinc application was not done i.e., $\mathrm{T}_{6}, \mathrm{~T}_{3}$ and $\mathrm{T}_{2}$

This might be due to the fact that foliar applied zinc ions possess high mobility within the plants leading to increased concentration of zinc in the seed, quality of seed, which in turn enhances the carbohydrates and protein concentration (Pandey et al., 2010). The lowest zinc content in the seed was recorded with control $\left(\mathrm{T}_{1}\right)$ as the soils are deficit in available zinc $\left(1.04 \mathrm{~kg} \mathrm{ha}^{-1}\right)$.

\section{References}

Alloway, B.J., 2004. Zinc in soils and crop nutrition. International Zinc Association, Brussels, Belgium.

Anitha, S., Sreenivasan, E and Purushothaman. 2005. Response of cowpea (Vigna unguiculata (L) Walp) to foliar nutrition of zinc and iron in the oxisols of Kerala. Legume Research. 28(4): 294-296.

Babu, S.P.N., Koppalkar, B.G., Desai, B.K., Nagalikar, V.P and Pramod Katti. 2012. Yield, yield components and economics of pigeonpea cultivation as influenced by organic manures and graded levels of zinc sulphate. Karnataka Journal of Agricultural
Sciences. 25(4): 527-530.

Beg, M.Z., Ahmad, S and Srivastava, D.K. 2013. Foliar application of potassium on urdbean. Indian Journal of Agricultural Sciences. 2(2): 67-70.

Chavan, A., Khafi, M.R., Raj, A.D and Parmar, R.M. 2012. Effect of potassium and zinc on yield, protein content and uptake of micronutrients on cowpea [Vigna unguiculata (L.) Walp.]. Agricultural Science Digest. 32(2): 175-177.

Demeterio, J.L., Ellis, R and Paulsen, G.M. 1972. Nodulation and nitrogen fixation by two soybean varieties as affected by phosphorus and zinc nutrition. Journal of Agronomy. 64: 564-568.

Katyal, J.C., 2012. Ferilizer use situation in India. Journal of the Indian Society of Soil Science. 49(4): 570-592.

Lowry, O.H., Resebrough, N.J., Farr, A.L and Rondal, R.J. 1951. Colorimetric method for estimation of protein. Journal of Biological Chemistry. 193: 265.

Mengal, K., 1976. Potassium in plant physiology and yield formation. Indian Society of Soil Science Bulletin. 10: 23-40.

Mostafavi, K., 2012. Grain yield and yield components of soybean upon application of different micronutrient foliar fertilizers at different growth stages. International Journal of Agriculture: Research and Review. 2(4): 389-394.

Nalini, P., Gupta, B and Pathak, G.C. 2013. Foliar application of zinc at flowering stage improves plant's performance, yield and yield attributes of blackgram. Indian Journal of Experimental Biology. 51: 548-555.

Pandey, S.K., Bahuguna, R.N., Pal, M., Trivedi, A.K., Hemantaranjan, A and Srivastava, J.P. 2010. Effects of pre 
treatment and foliar application of zinc on growth and yield components of mungbean (Vigna radiata L.) under induced salinity. Indian Journal of Plant Physiology. 15(2): 164-167.

Patel, P.C., and Kotecha, A.V. 2006. Effect of $\mathrm{P}$ and $\mathrm{K}$ on growth characters, forage yield, nutrient uptake and quality of Lucerne. Indian Journal of Agronomy. 51: 242-244.

Reddy, B.S., Reddy, S.R and Subbaiah, G. 1991. Effect of supplemental nutrition during post flowering phase of groundnut. The Andhra Agricultural Journal.38: 4-7.

Tandon, H.L.S., 1993. Methods of Analysis of Soils, Plants, Water and Fertilizers. Fertilizer Development and Consultation Organisation. New Delhi. 140.

Yadav, K.S., and Hira Nand. 2004. Sitespecific nutrient management for optional food grain production in Haryana. Better Crops with Plant Food. 88: 21-23.

\section{How to cite this article:}

Mohammad Javid Rahimi, Y. ReddiRamu, N. Sunitha and Umamahesh, V. 2019. Productivity and Quality of Greengram as Influenced by Potassium and Zinc Nutrition. Int.J.Curr.Microbiol.App.Sci. 8(06): 749-755. doi: https://doi.org/10.20546/ijcmas.2019.806.089 